\title{
ALUMINA PHASE TRANSFORMATION FROM THERMAL DECOMPOSITION OF AMMONIUM ALUM SYNTHESIZED FROM KANKARA KAOLIN
}

\author{
S. G. Bawa ${ }^{1}$, A. S. Ahmed ${ }^{2}$ and P.C. Okonkwo ${ }^{3, *}$ \\ 1,2,3 Department of Chemical EngineEring, Ahmadu Bello University, Zaria, Kaduna State. NigERIA \\ E-mail addresses:15gbawa@gmail.com, 2 asahmed2001@yahoo.com, ${ }^{3}$ chemstprom@gmail.com
}

\begin{abstract}
Thermal stability of transitional alumina phases produced from ammonium alum using Kankara kaolin as starting material was studied. Wet beneficiation method was employed to purify the starting material, after which it was calcined and dealuminated with sulphuric acid. The elemental composition, mineralogical, and physiological analyses were carried out using X-ray fluorescence (XRF), X-ray diffraction (XRD) and Brunauer-Emmett-Teller (BET) techniques respectively. The ammonium alum was thermally treated by varying the calcination temperature from 700 to $1200^{\circ} \mathrm{C}$ and varying the time of calcination from 1 to $4 \mathrm{~h}$. The formation of gamma alumina began at calcination temperature of $825^{\circ} \mathrm{C}$ for calcination time of $3 \mathrm{~h}$, which was found to be lower than reported works of $900^{\circ} \mathrm{C}$. It was found to be stable at higher temperature of $1125^{\circ} \mathrm{C}$, above which phase transformation to alpha alumina was observed. The observed wide range of thermal stability of the gamma alumina phase gives it good advantage to be used for high temperature applications, such as support for catalyst promoters. Alpha alumina phase formation began at $1150^{\circ} \mathrm{C}$ and was fully formed at $1200^{\circ} \mathrm{C}$. BET specific surface area of $166 \mathrm{~m}^{2} / \mathrm{g}$ was obtained for the gamma alumina phase which was high enough for it application as support for catalyst, catalyst and adsorbent.
\end{abstract}

Keywords: Kaolin, ammonium alum, gamma alumina, alpha alumina

\section{INTRODUCTION}

Alumina is one of the major components used as catalyst support, which is especially important with regard to precious-metal catalysts [1]. High surface area aluminas with porous structure have gained importance due to their potential applications as catalysts and catalyst supports as well as adsorptive materials in separation processes. Transitional alumina especially gammaalumina, has been a major catalytic support in automotive and petroleum industries, as well as in adsorption technology. Micro and nanocrystalline aluminas are commonly used for $\mathrm{Al}_{2} \mathrm{O}_{3}$-based ceramics [2]. Alumina remains a very important material used as a support for metal catalyst and zeolite catalysts which are used for processing petroleum, gas, petrochemicals and for other applications in the chemical processing industry [3,4].Alumina is one of the most used and advanced ceramic materials with applications ranging from spark plugs to catalyst materials [5]. Currently and for the foreseeable future, the most important types of nanoparticles which possess high specific surface area are simple oxides such as $\mathrm{Al}_{2} \mathrm{O}_{3}$, which are used in established applications [6], and for sapphire crystal growth [7]. Presently, alpha-alumina $\left(\alpha-\mathrm{Al}_{2} \mathrm{O}_{3}\right)$ has many uses in traditional and advanced ceramics. It is an important substrate for the growth of the superconductors and semiconductors by molecular beam [8].Alumina exists both in the transition or metastable and stable forms. Alpha $(\alpha)$ alumina is the only stable phase of alumina while the metastable phases include, chi $(\chi)$ phase, eta $(\eta)$ phase, $\operatorname{kappa}(\kappa)$ phase, theta $(\theta)$ phase, delta $(\delta)$ phase, and gamma $(\gamma)$ phase $[6,9]$. Transition aluminas may also be formed by pyrolysis of crystalline hydrates of aluminum saltssuch as sulphate, nitrate, ammonium alum and chloride [8]. Conventional methods for synthesizing $\alpha-\mathrm{Al}_{2} \mathrm{O}_{3}$ involve solid state thermally driven transformations from the hydrates of aluminum oxide. The extent and total conversion to the corundum structure, which depends on the temperature and the time of thermal treatment occurs on heating above $1230^{\circ} \mathrm{C}$ [6].Bauxite has been widely used in industry to produce alumina via the Bayer process, while nonbauxitic materials which are more abundant in many countries, have been processed in attempts to develop alternative technologies for alumina production. Examples of such nonbauxitic raw materials include: alunite, sillimanite, and alusite, kyanite, kaolin, mica and fly ash [10]. Due to the decline in bauxite reserve (both

* Corresponding author, tel: + 234-803-451-6186 
qualitatively and quantitatively) and the need to explore the use of locally sourced raw materials, various research works had been carried out and it has been shown that kaolin clay (which is next to bauxite in alumina content), can be used for alum production [11] and alumina [12]. Ammonium alum $\left(\mathrm{NH}_{4}\right)_{2} \mathrm{SO}_{4} \cdot \mathrm{Al}_{2}\left(\mathrm{SO}_{4}\right)_{3} \cdot 24 \mathrm{H}_{2} \mathrm{O}$, a white crystalline double sulphate of aluminum is used in water purification, vegetable glues, porcelain cements, natural deodorant and in fire proofing textiles. Ammonium alum $\left(\mathrm{NH}_{4} \mathrm{Al}\left(\mathrm{SO}_{4}\right)_{2} \cdot 12 \mathrm{H}_{2} \mathrm{O}\right)$ is a potential starting material for preparation of high purity reactive alumina [13]. Several works that had been reported on Kankara kaolin include, single alum that had been produced from Kankara kaolin clay and met industrial requirements [14], preliminary investigation of alumina production from single alum [15],production of double alum from Kankara kaolin [11], extraction of alumina from ammonium alum [13, 16],gamma alumina from aluminum hydroxide prepared from Kankara kaolin [17].

Despite the works carried out on Kankara kaolin, no work has been done to investigate the transitional phases present during the thermal decomposition of ammonium alum prepared from Kankara kaolin. The phase transition temperature from the metastable to stable phase of alumina has not been investigated via thermal decomposition of ammonium alum prepared from Kankara kaolin which is thrust of this study. Thus, this study involves preparation of ammonium alum from the filtrate of dealumination of metakaolin. The effect of thermal treatment of the ammonium alum was closely studied as the calcination temperature and time were varied. The alumina phases transformation was also monitored as the thermal conditions were changed.

\section{MATERIALS AND METHOD}

\subsection{Materials}

The kaolinite clay was sourced from Kankara town of Katsina State, Nigeria. The reproducibility of the alum from the kaolin at Kankara deposit at different sampling point had been proven. Industrial grade concentrated sulphuric acid, 96wt\% (Johnson Solomon Chemicals, London) was used for the metakaolin dealumination. Ammonium sulphate Analar grade (BDH, Chemicals LTD, England) was used as the salting agent to obtain the ammonium alum crystals.

\subsection{Methods}

\subsubsection{Kaolin purification and calcination}

Raw kaolinite clay was purified using the wet beneficiation method $[18,19]$. The dried beneficiated kaolin was thermally activated in an exposed electric element furnace (Nabertherm; $30-1400^{\circ} \mathrm{C}$ ) at $750^{\circ} \mathrm{C}$ for calcination time of $2 \mathrm{~h}$ to obtain metakaolin [20], the reactive phase of disordered kaolin as shown in Equation (1).

\subsubsection{Dealumination}

The alumina content of the amorphous metakaolin was leached in the reaction medium of $60 \mathrm{wt} \%$ sulphuric acid using the novel method approach of dealumination [20, 21]. The dealumination mixture was then filtered using a high vacuum pump (Edwards ES50) filtration set-up. The products obtained was liquid aluminum sulphate and unreacted silica as residue. The reaction is represented in Equation (2).

\subsubsection{Crystallization}

Prior to crystallization, the mixture was diluted with 288 $\mathrm{cm}^{3}$ of distilled water, reducing the acidic nature of the mixture from $60 \mathrm{wt} \%$ to $30 \mathrm{wt} \%$. This was done to enhance the ease of separation of the excess acid from the alum by taking advantage of the freezing point depression of sulphuric acid solutions on dilution. The filtrate was then cooled at temperature of $0^{\circ} \mathrm{C}$ for $6 \mathrm{~h}$ [22]. Ammonium sulphate was added to the filtrate as a salting agent to produce ammonium alum. Equation (3) shows the crystallization reaction.

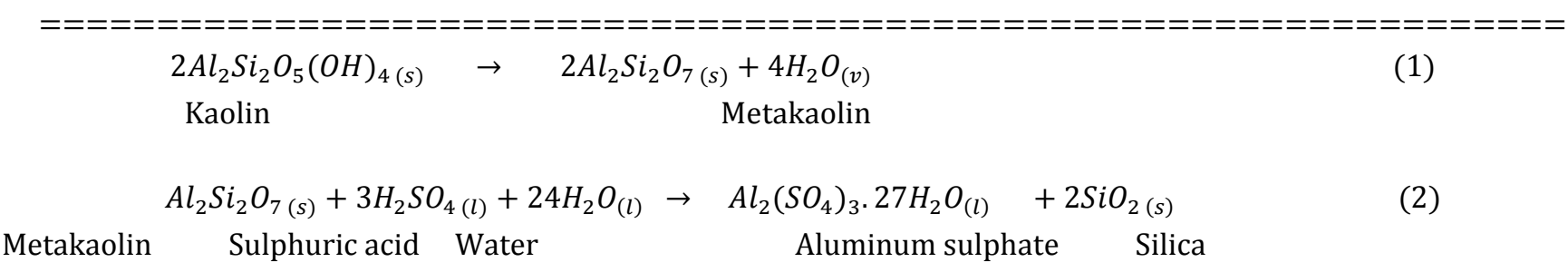

$$
\left(\mathrm{NH}_{4}\right)_{2} \mathrm{SO}_{4(s)}+\mathrm{Al}_{2}\left(\mathrm{SO}_{4}\right)_{3(l)}+24 \mathrm{H}_{2} \mathrm{O}_{(l)} \rightarrow\left(\mathrm{NH}_{4}\right)_{2} \mathrm{SO}_{4} \cdot \mathrm{Al}_{2}\left(\mathrm{SO}_{4}\right)_{3} \cdot 24 \mathrm{H}_{2} \mathrm{O}_{(s)}
$$
Ammonium sulphate Aluminum sulphate water

Ammonium alum

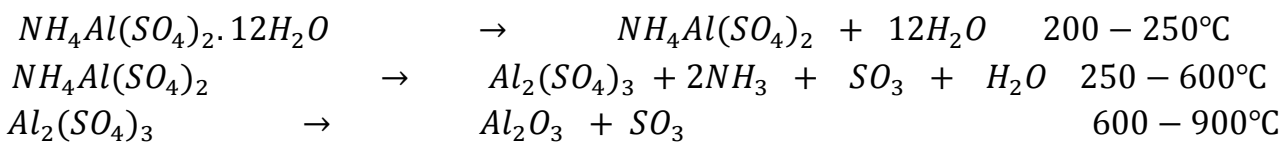




\subsubsection{Thermal Treatment}

The wet ammonium alum was heated to $250^{\circ} \mathrm{C}$ for $4 \mathrm{~h}$ to expel the water of crystallization. The dried ammonium alum was calcined in the electric furnace at various temperature ranging from 700 to $1200^{\circ} \mathrm{C}$ and calcination time ranging from 1 to $4 \mathrm{~h}$. Single alum decomposition begins at about $700^{\circ} \mathrm{C}$ and alpha alumina is usually obtained at about $1200^{\circ} \mathrm{C}$, these findings informed the choice of the calcination temperatures for this study. Equations (4) to (6), show the step-wise thermal decomposition of the ammonium alum. Physicochemical characterization of the products was carried out via different techniques.

\subsubsection{Characterization Techniques}

The elemental composition (in oxide form) of the starting material, intermediate and final products were determined using the XRF machine (Minipal 4, PANalytical). XRD patterns were obtained using Empyreal, PANalytical diffractometer employing $\mathrm{Cu} \mathrm{K \alpha}$ radiation with $\lambda=0.154 \mathrm{~nm}$, the range of the Bragg's angle for the analysis was from 4 to $75^{\circ}$, operated at continuous scanning, scanning speed of $5^{\circ} / \mathrm{min}$, generator settings of $10 \mathrm{~mA}$ and $40 \mathrm{kV}$. The textural properties (surface area, pore size and pore volume), of the products were determined using BET method by $\mathrm{N}_{2}$ adsorption at $-196^{\circ} \mathrm{C}$ using Tristar 3000 Micrometrics equipment.

\section{RESULTS AND DISCUSSION}

\subsection{X-ray Fluorescence}

The chemical compositions of Kankara kaolin, beneficiated kaolin, metakaolin and the alumina products obtained at calcination temperature of $800^{\circ} \mathrm{C}$ are presented in Table 1 . The alumina content increases steadily with beneficiation, which is the aim of the process.ilica content was observed to also increase numerically, this was not in the same proportion with the alumina. This implies that the materials removed during the beneficiation process were high in silica content, basically, montmorillonite, mica and quartz. The silica to alumina ratio calculated from the XRF analysis result shown in Table 1 for metakaolin was approximately 2, which agreed with the literature value[23]. It was also an indication that at the calcination temperature of $750^{\circ} \mathrm{C}$ for $2 \mathrm{~h}$, complete conversion of kaolin to metakaolin had occurred. Thermal decomposition of aluminum sulphate had been reported to commerce at $800^{\circ} \mathrm{C}$ [24]. The maximum alumina content obtained at this calcination temperature was $39 \%$ for $3 \mathrm{~h}$ calcination time, this low value and high value of the sulphate content of $59 \%$ gave an indication that the desired alumina phase was yet to be formed. Calcination time of $3 \mathrm{~h}$, however was used for further thermal treatment, since within experimental error the average alumina content for $3 \mathrm{~h}$ and $4 \mathrm{~h}$ were same as observed in Table 1.

Steady increase of alumina content was observed from $700^{\circ} \mathrm{C}$ to $800^{\circ} \mathrm{C}$, while a rapid increase was observed between $800^{\circ} \mathrm{C}$ to $850^{\circ} \mathrm{C}$, while the same trend was noticed with the sulphate composition in the opposite direction as seen in Table 2.

This sudden increase was an indication of phase change of the material. As such the thermal decomposition of aluminum sulphate to alumina would have started between 800 and $850^{\circ} \mathrm{C}$. The steady increase continued from $850^{\circ} \mathrm{C}$ to $1200^{\circ} \mathrm{C}$ with a steady decrease of the sulphate component as shown graphically in Figure 1. The assertion of phase change from aluminum sulphate to alumina was still subject to further verification.

Table 1: XRF analysis for the starting material, intermediate products and preliminary calcination

\begin{tabular}{|c|c|c|c|c|c|c|c|}
\hline \multirow[t]{2}{*}{ Oxides } & \multirow[t]{2}{*}{$\mathrm{RK}$} & \multirow[t]{2}{*}{$\mathrm{BK}$} & \multirow[t]{2}{*}{ MK } & \multicolumn{4}{|c|}{$800^{\circ} \mathrm{C}$} \\
\hline & & & & $1 \mathrm{~h}$ & $2 \mathrm{~h}$ & $3 \mathrm{~h}$ & $4 \mathrm{~h}$ \\
\hline $\mathrm{Al}_{2} \mathrm{O}_{3}$ & 33.41 & 37.80 & 42.06 & 30.40 & 29.40 & 39.00 & 38.90 \\
\hline $\mathrm{SiO}_{2}$ & 45.10 & 47.48 & 49.90 & 2.20 & ND & ND & ND \\
\hline $\mathrm{SO}_{3}$ & ND & ND & ND & 65.02 & 67.44 & 59.21 & 58.97 \\
\hline $\mathrm{Na}_{2} \mathrm{O}$ & 0.693 & 0.270 & 0.12 & 0.04 & 0.06 & 0.05 & 0.04 \\
\hline $\mathrm{K}_{2} \mathrm{O}$ & 1.49 & 0.544 & 0.427 & 0.01 & 0.09 & 0.07 & 0.15 \\
\hline $\mathrm{MgO}$ & 0.016 & 0.05 & 0.038 & 0.36 & 0.40 & 0.18 & 0.19 \\
\hline $\mathrm{CaO}$ & 0.343 & 0.325 & 0.289 & 0.68 & 1.80 & 0.12 & 0.40 \\
\hline $\mathrm{Fe}_{2} \mathrm{O}_{3}$ & 0.555 & 0.562 & 0.483 & 0.82 & 0.66 & 0.81 & 0.86 \\
\hline Others & ND & ND & ND & 0.43 & 0.23 & 0.28 & 0.49 \\
\hline $\mathrm{SiO}_{2} / \mathrm{Al}_{2} \mathrm{O}_{3}$ & 2.29 & 2.14 & 2.02 & NA & NA & NA & NA \\
\hline
\end{tabular}

RK: Raw kaolin BK: Beneficiated kaolin MK: Metakaolin ND: Not detected NA: Not applicable 
Table 2: Chemical composition of alumina calcined at higher temperature at $3 \mathrm{~h}$ calcination time

\begin{tabular}{lrclllcccccc}
\hline & $700^{\circ} \mathrm{C}$ & $750^{\circ} \mathrm{C}$ & $800^{\circ} \mathrm{C}$ & $850^{\circ} \mathrm{C}$ & $900^{\circ} \mathrm{C}$ & $950^{\circ} \mathrm{C}$ & $1000^{\circ} \mathrm{C}$ & $1050^{\circ} \mathrm{C}$ & $1100^{\circ} \mathrm{C}$ & $1150^{\circ} \mathrm{C}$ & $1200^{\circ} \mathrm{C}$ \\
\hline $\mathrm{Al}_{2} \mathrm{O}_{3}$ & 28.40 & 30.10 & 39.00 & 85.02 & 89.20 & 91.90 & 92.30 & 92.60 & 93.10 & 93.50 & 93.90 \\
$\mathrm{SiO}_{2}$ & 1.82 & $\mathrm{ND}$ & $\mathrm{ND}$ & $\mathrm{ND}$ & $\mathrm{ND}$ & 0.20 & 0.21 & 0.23 & 0.29 & 0.11 & 0.61 \\
$\mathrm{SO}_{3}$ & 68.55 & 68.94 & 59.21 & 7.76 & 3.55 & 0.90 & 0.80 & 0.74 & 0.30 & 0.20 & 0.17 \\
$\mathrm{Na}_{2} \mathrm{O}$ & 0.08 & 0.03 & 0.05 & 0.04 & 0.03 & 0.10 & 0.11 & 0.10 & 0.12 & 0.16 & 0.12 \\
$\mathrm{~K}_{2} \mathrm{O}$ & 0.15 & 0.10 & 0.07 & 0.48 & 0.28 & 0.27 & 0.27 & 0.26 & 0.28 & 0.39 & 0.22 \\
$\mathrm{MgO}$ & 0.10 & 0.12 & 0.18 & 0.10 & 0.08 & 0.09 & 0.09 & 0.08 & 0.09 & 0.08 & 0.07 \\
$\mathrm{CaO}$ & 0.25 & 0.10 & 0.12 & 0.15 & 0.17 & 0.25 & 0.24 & 0.22 & 0.23 & 0.28 & 0.43 \\
$\mathrm{Fe}_{2} \mathrm{O}_{3}$ & 0.58 & 0.60 & 0.81 & 2.67 & 2.87 & 3.43 & 2.89 & 2.62 & 2.65 & 1.82 & 1.44 \\
Others & 0.32 & 0.17 & 0.28 & 3.65 & 3.63 & 2.92 & 3.15 & 3.09 & 2.91 & 3.46 & 3.61 \\
\hline
\end{tabular}

*ND: Not detected

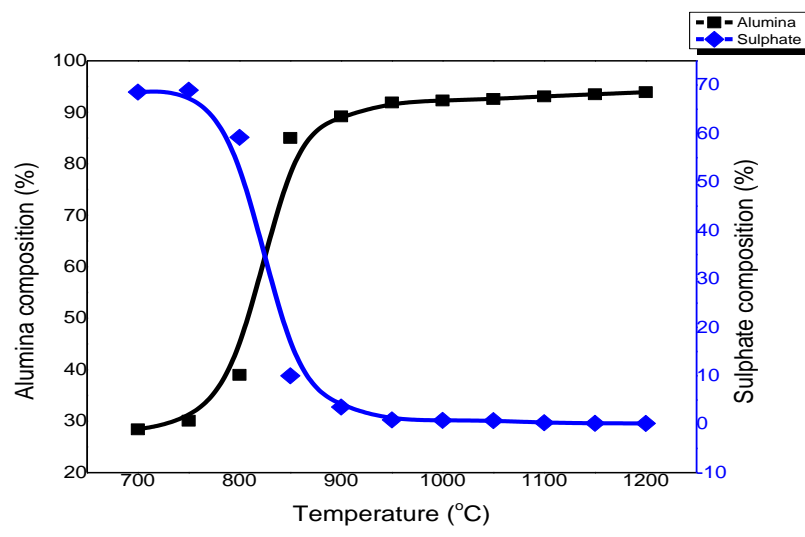

Figure 1: Variation in alumina and sulphur content with temperature of thermally treated ammonium alum

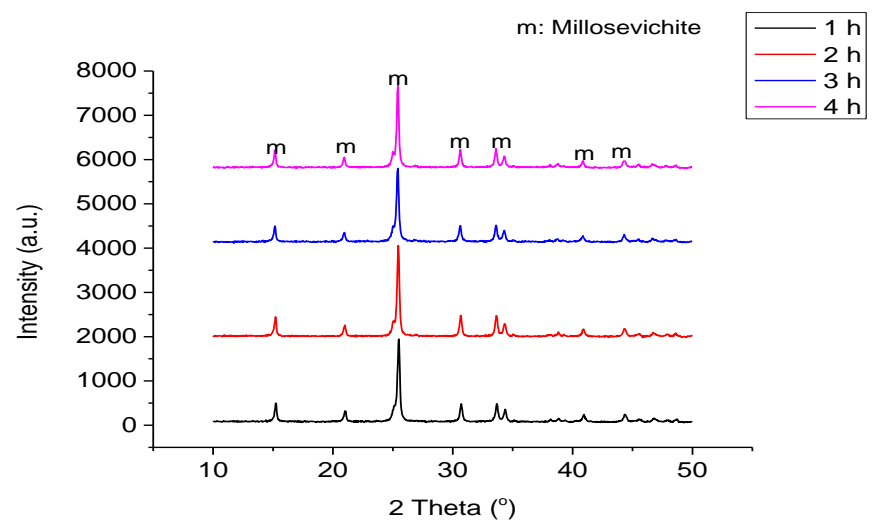

Figure 3: Ammonium alum calcined at $800^{\circ} \mathrm{C}$ for varying calcination time

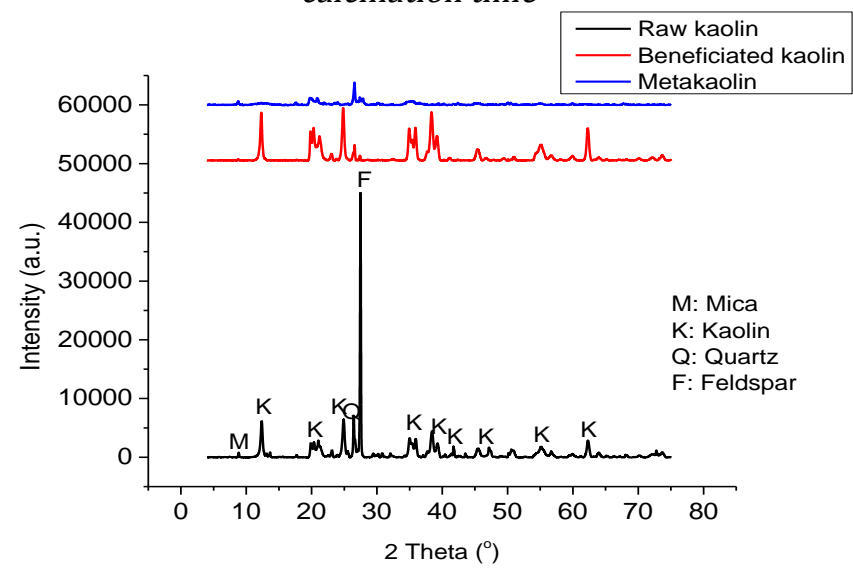

Figure 2: XRD pattern for Kankara kaolin, beneficiated and metakaolin

\subsection{XRD Analysis}

The XRD pattern of the raw Kankara kaolin was crystalline as evident by its high intensity counts as seen in Figure 2. The high peak at Bragg angle of about $27.5^{\circ}$ was an impurity. It was found to be Microline a potassium rich alkali feldspar. It was not strange because feldspar is one of the impurity that is associated with kaolin among several others. But it was soluble as was observed from the high reduction of the peak after wet beneficiation process, as shown in Figure 2. This was also confirmed by the decrease of the $\mathrm{Na}_{2} \mathrm{O}$ and $\mathrm{K}_{2} \mathrm{O}$ contents from the raw to the beneficiated kaolin, from the XRF analysis. From the XRD patterns shown in Figures 2, the characteristics peaks of kaolinite [18, 25] were found which occur at Bragg's angle of 12.35, 19.89, 20.38, $24.88,35.02,35.95,36.06,38.35$, and $62.37^{\circ}$. The XRD pattern of metakaolin was observed to be amorphous, owing to the low intensity counts as well as broad peaks (Figure 2). The observation was as expected due to collapse of the structure by the $\mathrm{OH}$ group that is inbetween the plate-like nature of the kaolin, which led to disorderly arrangement. But the fine quart was still present as seen by its characteristic peak at Bragg's angle of $26.6^{\circ}$. Mica was as an impurity, found in the raw kaolin but also decreased after beneficiation of the raw kaolin.

No phase transformation occurred during the thermal treatment of the ammonium alum at $800^{\circ} \mathrm{C}$ for different calcination time, which was in agreement with the observation of the XRF analysis in Table 1. The product obtained was found to be Millosevichite mineral (anhydrous form of aluminum sulphate), which was crystalline as evident by the sharp peaks and high intensity counts, revealed by the XRD pattern as can be seen in Figure 3. The XRD patterns were similar depicting same product obtained.

Further calcination to $825^{\circ} \mathrm{C}$ confirmed the formation of gamma alumina phase, with its characteristic broad peaks at Bragg's angle of $37.7,46.1$ and $66.7^{\circ}$, which was amorphous. This observation showed that, the transformation of crystalline aluminum sulphate to gamma alumina began at $825^{\circ} \mathrm{C}$ as observed in Figure 4, which was lower than $900^{\circ} \mathrm{C}$ earlier reported $[10,17$, 24]. Since gamma alumina is not the only transitional 
phase of alumina, calcination at higher temperature was done to investigate the presence of other transitional phases of alumina, but from the XRD pattern which is one of the indicative measures to note other transitional phases did not reveal the formation of any other phase other than the gamma alumina. Among other transitional phases of alumina obtained from thermal transformation of aluminum hydroxide from bauxite [8], gamma alumina has shown good properties especially in terms of the specific surface area, as such it is the most widely used transitional phase of alumina for catalytic applications. Its stability over thermal treatment is of great importance and added advantage.

It was observed from the XRD pattern presented in Figure 4, that the gamma alumina phase was stable up to the calcination temperature of $1125^{\circ} \mathrm{C}$ which was higher than reported value of $1030^{\circ} \mathrm{C}$ [10]. New peaks were observed at temperature of $1150^{\circ} \mathrm{C}$ corresponding to Bragg's angle of 25.6. 35.2, 37.9, 43.4, 52.6, 57.6, 66.5 and $68.3^{\circ}$, which was fully developed at $1200^{\circ} \mathrm{C}$. The XRD pattern at the calcination temperature of $1200^{\circ} \mathrm{Cshowed}$ a complete phase transformation into the alpha alumina phase $[5,6,8,25]$.

\subsection{BET analysis}

Specific surface area is very critical parameter of a porous material when used as a catalyst or catalyst support in which gamma alumina is mostly use. The textural properties (surface area, pore size and pore volume). The highest specific surface area was observed at calcination temperature of $850^{\circ} \mathrm{C}$ having value of 166 $\mathrm{m}^{2} / \mathrm{g}$ which was higher than previous reported value of gamma alumina synthesized from the same source but via different routes $[13,17]$. The specific surface area was gradually being lost as the calcination temperature increases, as can be seen in Figure 5, this could be attributed to gradual internal structural change within the gamma alumina. The low value of the specific surface area of alpha alumina makes it unsuitable for application in catalysis, despite its high stability. The products obtained had relatively large pore sizes $(20 \mathrm{~nm}-30 \mathrm{~nm})$; resistance to mass flow in and out of the pores will be negligible when in use. Large pore volume was observed at calcination temperature of $850^{\circ} \mathrm{C}$ and $900^{\circ} \mathrm{C}$ $\left(1.21 \mathrm{~cm}^{3} / \mathrm{g}\right.$ and $1.15 \mathrm{~cm}^{3} / \mathrm{g}$ respectively), as presented in Figure 6. This indicated that diffusion resistance within the pore cavity will not pose a serious challenge.

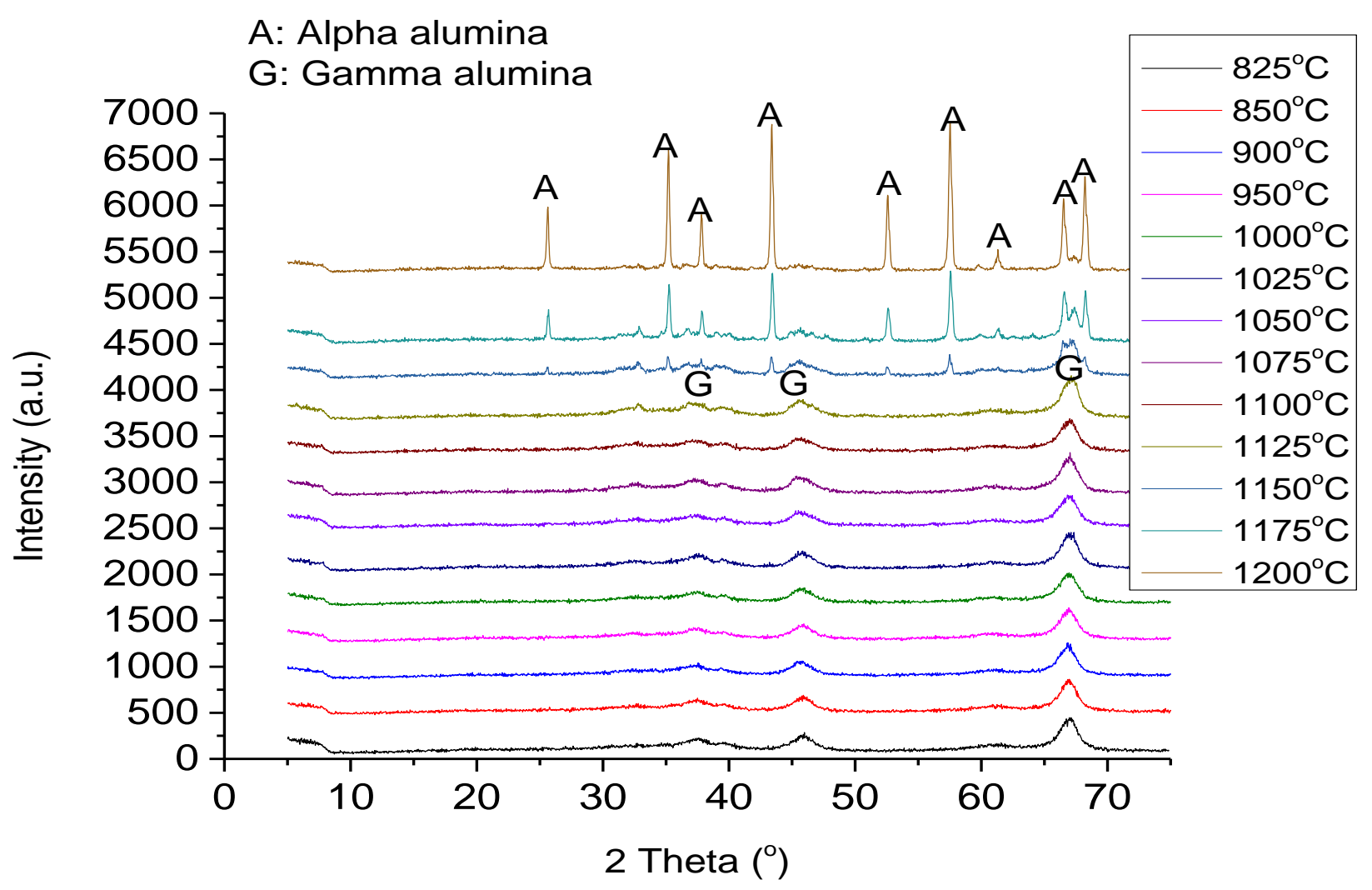

Figure 4: XRD patterns of alumina obtained at various calcination temperature 


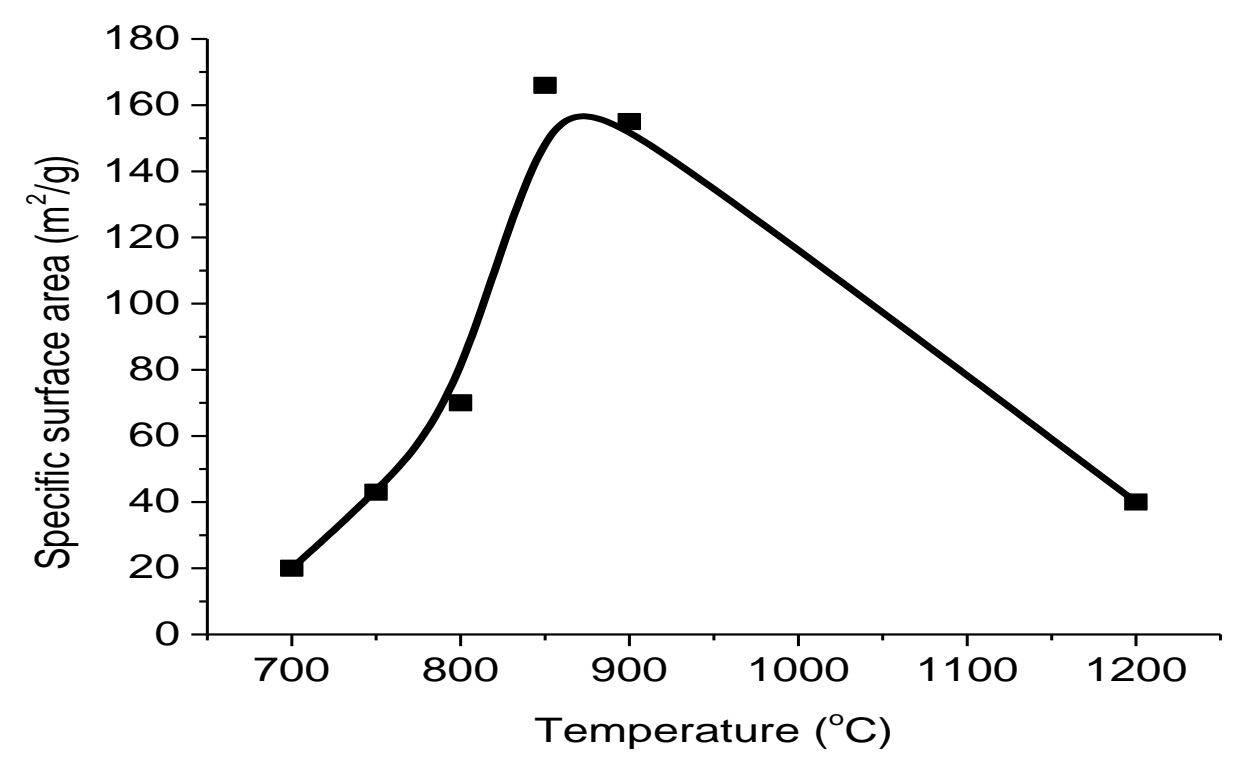

Figure 5: Alumina specific surface area variation with variation of temperature

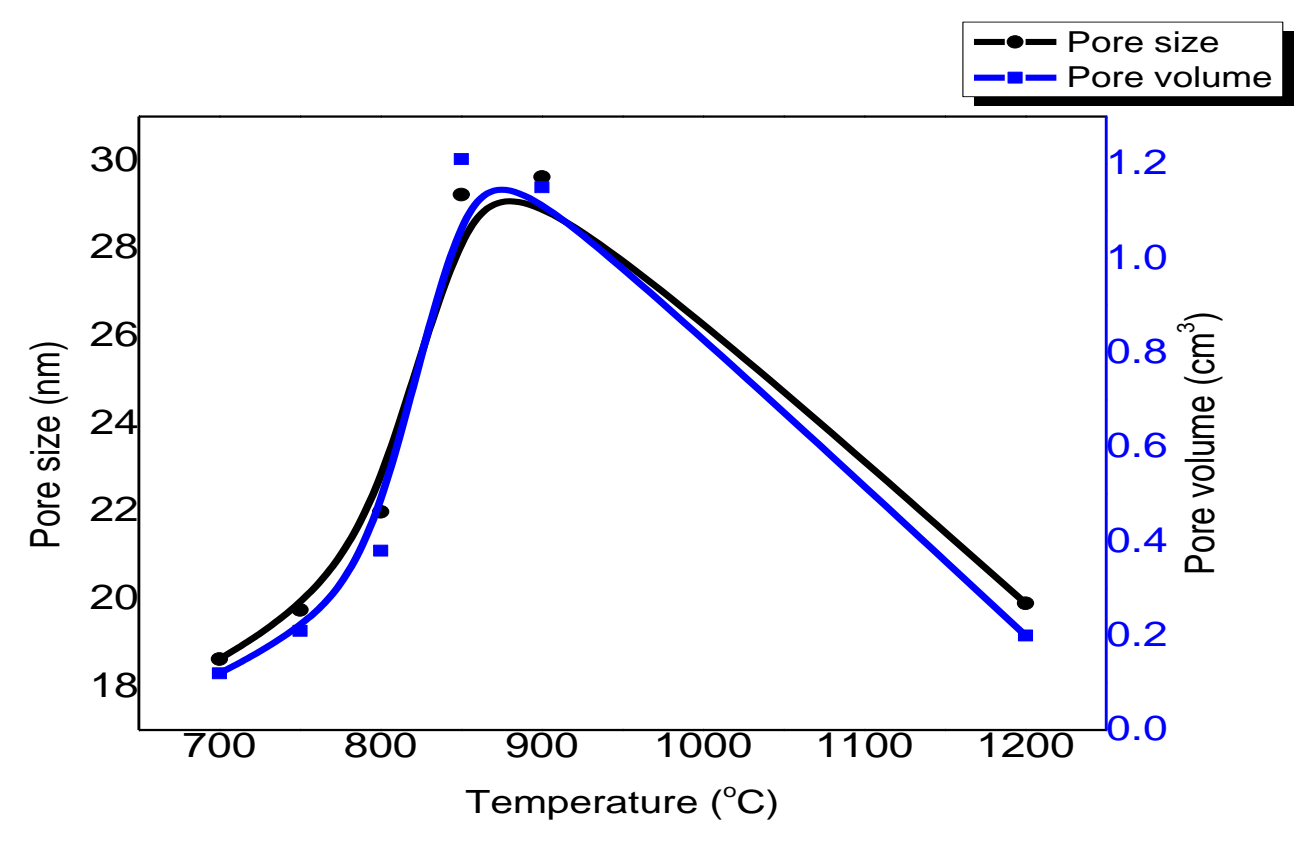

Figure 6: Effect of calcination temperature on alumina pore size and volume

\section{CONCLUSION}

Pure crystalline phase of aluminum sulphate was observed during calcination of ammonium alum prepared from Kankara kaolin at $800^{\circ} \mathrm{C}$, irrespective of the calcination time. The formation of gamma alumina from thermal decomposition of ammonium alum began at $825^{\circ} \mathrm{C}$. The best temperature for obtaining gamma aluminafrom this investigationwas $850^{\circ} \mathrm{C}$ having the highest specific surface area of $166 \mathrm{~m}^{2} / \mathrm{g}$. The transformation from gamma to alpha alumina occurs between the temperature ranges of $1125-1175^{\circ} \mathrm{C}$. Fully developed alpha alumina phase was developed at $1200^{\circ} \mathrm{C}$. The highest alumina content was $94 \%$ found in the alpha alumina phase.

\section{ACKNOWLEDGEMENT}

The authors are grateful to Petroleum Technology Development Fund, Abuja for their funding.

\section{REFERENCES}

[1] Akia, M., Alavi, S. M. and Yan, Z."Dehygrogenation Catalysts of Higher Normal Paraffins on a Nanocrystalline $\gamma-\mathrm{Al}_{2} \mathrm{O}_{3} \quad$ Support: Different Impregnation Sequences" Journal of Petroleum and Gas Engineering. Vol. 2, Number 3, , pp 64-73. 2011.

[2] Naik, B. and Ghosh, N. N. "A Review on Chemical Methodologies for Preparation of Mesoporous Silica and Alumina Based Materials", Recent Patents on Nanotechnology, Vol. 3, , pp 213-224, 2009. 
[3] Phung, T. K., Lagazzo, A., Crespo, M. Á. R., Scribano, V.S., Busca, G. "A Study ofCommercial Transition Aluminas and of their Catalytic Activity in the Dehydration of Ethanol", Journal of Catalysis, Vol. 311, pp 102-113, 2014.

[4] Zhang, Q., Xu, J., Fan, F., Sun, D., Xu, G., Zhang, S., Zhu, Z."Application of Porous AnodicAlumina Monolith Catalyst in Steam Reforming of Dimethyl ether: $\mathrm{Cu} / \gamma-\mathrm{Al}_{2} \mathrm{O}_{3} / \mathrm{Al}$ Catalyst Degradation Behaviors and Catalytic Activity Improvement by PrecompetitionImpregnation Method",Fuel Processing Technol. Vol. 119, pp 52-59, 2014.

[5] Meor-Yusoff, M. S. and Masliana, M.“Synthesis of Alumina Using the Solvo Thermal Method", The Malaysian Journal of Analytical Science, Vol. 11, Number 1, pp 262-268, 2007.

[6] Cava, S., Tebcherani, S. M., Souza, I. A., Pianaro, S. A., Paskocimas, C. A., Longo, E. and Varela, J. A. "Structural Characterization of Phase Transition of $\mathrm{Al}_{2} \mathrm{O}_{3}$ Nanopowders Obtained by Polymeric Precursor Method", Journal of Material Chemistry and Physics, Vol. 103, pp 394-399, 2007.

[7] Lee, S. J., Kim, H. S., Park, N., Lee, T. J., Kang, M.“Low temperature synthesis of alpha alumina from aluminum hydroxide hydrothermally synthesized using $\left[\mathrm{Al}\left(\mathrm{C}_{2} \mathrm{O}_{4}\right)_{\mathrm{x}}(\mathrm{OH}) \mathrm{y}\right]$ complexes", Chemical Engineering Journal, Vol. 230, pp 351-360, 2013.

[8] Santos, P. S., Santos, S. H. and Toledo, S. P. "Standard Transition Aluminas. Electron Microscopy Studies", Material Resources Journal, Vol. 3 Number 4, 2000.

[9] Kloprogge, J. T., Ruan, H. D. and Frost, R. L. "Thermal Decomposition of Bauxite Minerals: Infrared Emission Spectroscopy of Gibbsite, Boehmite and Diaspore", Journal of Materials Science, Vol. 37, Number 6, pp 1121-1129, 2002.

[10] Hosseini, S. A., Niaei, A. and Dariush, S.“Production of $\gamma-\mathrm{Al}_{2} \mathrm{O}_{3}$ from Kaolin", Open Journal of Physical Chemistry, Vol. 1, pp 23-27, 2011.

[11] Edomwonyi-Otu, L. and Aderemi, B. O. "Alums from Kankara Kaolin", Journal of Research in Engineering, Vol. 6, Number 1, 2009, pp 105-111, 2009.

[12] Bawa S. G., Ahmed, A. S. and Okonkwo P. C. "Development of nano-sized alpha-alumina ( $\alpha$ $\mathrm{Al}_{2} \mathrm{O}_{3}$ ) from indigenous kaolin Source", Nigerian Society of Chemical Engineers Conference/A.G.M, on Harnessing Water Resources for National Development, Abuja Nigeria, November 15-17, 2012.

[13] Aderemi, B. O. and Hameed, B. H. "Alumina from Kaolin - Extraction and Characterization" Nigerian Metallurgical Society Conference/A. G. M, 2011.
[14] Aderemi, B. O., Ahmed, A.S. and Abdul B.D."Production of Alum from Kankara Clay", Journal of Nigerian Society of Chemical Engineers, Vol. 21, Number 1, pp 120-124, 2006.

[15] Abdul, B. "Production of Alumina from Kankara Kaolin Clay", An M.Sc. Thesis Department of Chemical Engineering, Ahmadu Bello University, Zaria, 2005.

[16] Ahmed, A. S. and Bawa, S. G. "Development of Large Surface Area Alumina from Kaolin for Zeolite Support", International Symposium on Zeolites and Micro-Porous Crystals (ZMPC), Hiroshima, Japan, July 28 - August 1, 2012.

[17] Salahudeen, N., Ahmed, A. S., Al-Muhtaseb, A. H., Dauda, M., Waziri, S. M. and Jibril, B. Y."Synthesis of Gamma Alumina from Kankara Kaolin Using a Novel Technique", Applied Clay Science, Vol.105, pp 170177, 2014.

[18] Ahmed, A. S., Salahudeen, N., Ajinomoh, C. S., Hamza, H., and Ohikere, A. "Studies on the Mineral and Chemical Characteristics of Pindiga Bentonitic Clay", Petroleum Technology Development Journal, (ISSN 1595-9104) Vol. 1, 2012.

[19] Ahmed, A. S. and Onaji, P. B."The Effect of Beneficiation on the Properties of Some Nigerian Refractory Clays" Journal of Nigerian Society of Chemical Engineers, Vol. 6, Number 2, pp 119-129, 1987.

[20] Aderemi, B. O., Edomwonyi-Otu, L. and Adefila, S. S."A New Approach to Metakaolin Dealumination", Australian Journal of Basic and Applied Science. Vol. 3, Number 3, pp.2243-2248, 2009.

[21] Ajayi, A. O., Atta, A.Y., Aderemi, B. O. and Adefila, S. S. "Novel Method of Metakaolin Dealumination" Journal of Applied Sciences Research, Vol. 6, Number 10, pp 1539-1546, 2010.

[22] Aderemi, B. O., Oloro, E.F., Joseph, D. and Oludipe, J. "Kinetics of the Dealumination of Kankara Kaolin Clay", Nigerian. Journal of Engineering, Vol. 9, Number 1, pp 40-44, 2001.

[23] Bustanafruza F., Jafar-Tafreshi M., Fazlib M. "Studies on Thermal Decomposition of Aluminum Sulfate to Produce Alumina Nano Structure", Journal of Nanostructure, Vol. 2, pp 463-468, 2013.

[24] Grim, R. E. Clay Mineralogy, McGraw-Hill Book Co. Inc., 1953, pp 46, 212.

[25] Chen, P., Table of key lines in X-ray powder diffraction patterns of minerals in clays and associated rocks. Bloomington, Indiana, 1977. 